\title{
Sesamoid Bone
}

National Cancer Institute

\section{Source}

National Cancer Institute. Sesamoid Bone. NCI Thesaurus. Code C33541.

Any short, irregular bone that is embedded in a tendon, and which functions to alter the direction of muscle pull, diminish friction, and modify pressure; sesamoid bones are found in various locations in the body, the largest of which is the patella. 